\title{
耐震診断結果に基づく公営集合住宅建物の地震被害率の予測に関する研究 A STUDY ON PREDICTION OF DAMAGE RATIO OF PUBLIC MANAGEMENT APARTMENT BUILDINGS DUE TO EARTHQUAKE BASED ON SEISMIC PERFORMANCE INDEX
}

\author{
白瀬 陽一*1, 榊原啓太 ${ }^{* 1}$, 福和伸夫*2, 護 雅 史*3 \\ Yoichi SHIRASE, Keita SAKAKIBARA, Nobuo FUKUWA \\ and Masafumi MORI
}

\begin{abstract}
In this paper, an earthquake response analysis model based on seismic performance indices is proposed to evaluate actual seismic performance of public management apartment buildings appropriately. Damage ratio of buildings are calculated using this proposed model and observed seismic ground motions during the 1995 Hyogo-ken Nanbu Earthquake. As a result, the relationships between an index of seismic ground motion and calculated damage ratio of buildings show good agreement with vulnerability functions based on actual damage data of buildings in the 1995 Hyogo-ken Nanbu Earthquake. Through this study, it is pointed out that damage ratio of buildings could be overestimated, if load carrying capacity which has not been considered in the seismic design is not properly evaluated. Additionally, it is shown that the effect of slit on reinforced concrete wall has a big influence on the damage ratio of buildings.
\end{abstract}

Keywords : Public management apartment buildings, Seismic performance index, Earthquake response analysis model, Damage ratio of buildings, Earthquake damage prediction, Slit on reinforced concrete wall 公営集合住宅建物, 而震骖断結果, 地震応答解析モデル, 建物被害率, 地震被害予測, 構造スリット

1. はじめに

近年、建築基準法は「仕様規定」から「性能規定」へと改訂がな されており、建物の設計者は設計時に、建築主に対して、耐震性能 を含む建物の性能を説明することが要求されている。そのため、設 計者は、建物が遭遇すると予測される地震動に対して、被災時の建 物の状況(被害状況を含む) を精度よく予測することが重要となる。 このことは、耐震診断を行う場合も、同様だと考えられる。

一方で、1995 年兵庫県南部地震において、新耐震基準の想定を大 きく上回るレベルの地震動が観測されたにもかかわらず1、鉄筋コ ンクリート造(以下、 $\mathrm{RC}$ 造)建物の被害率は高くなかったこと常が指 摘されている。これは設計の考え方として、荷重や部材の耐力など を安全側に評価することや、設計時に考慮していない要因が建物の 被害率に影響していると考えられる。

また、兵庫県南部地震を契機に、公共性の高い建物を中心に全国 各地で耐震診断が精力的に行われている。耐震診断は、実建物の耐 震性能を評価する一つの有効な手法である。そのため従来から、耐 震診断結果を利用した建物の被害予測 ${ }^{3}$ や、耐震診断結果と建物被 害の関係に着目した研究占が行われている。

集合住宅建物は、而震診断值が低い割に被害が少なく、診断結果 が実耐力を過小評価する傾向にあることが指摘されている5
物の耐震改修の促進に関する法律が平成 18 年 1 月に改正、施行され、 平成 27 年度までに住宅の耐震化率を 9 割とする具体的な目標が定め られた。このこともあり、各自治体で数多くの公営集合住宅建物の 耐震診断が実施されているが、耐震改修・補強は、他の用途の RC 造建物に比べて余り進んでいない6)。その理由として、集合住宅建 物の用途上、耐震改修工事期間中も継続使用が求められる場合が多 いこと、補強により住宅の使い勝手が悪くなるなどの使用制限が起 きてしまうことなどが挙げられる。一方、公営集合住宅建物には、 外国人や高齢者、低所得者などが多く居住しており、建物の耐震化 が遅れると、災害時に弱い立場の人々に人的並びに物的な被害を与 える可能性が高い。

耐震診断結果に基づいて実被害を説明可能な方法を構築できれば、 而震診断結果と想定被害を結び付けて説明することが出来るため、 耐震診断の説明性が増し、耐震診断およびその後の耐震補強を促進 することの一助となると考える。さらに、最近精力的に行われてい るシナリオ型地震の強震動予測結果を組み合わせることにより、地 域固有の地震環境と建物固有の耐震性能に基づく、より精度の高い 建物の被害予測が可能になる。このためには、唯一の被害データと 言っても過言ではない 1995 年兵庫県南部地震の被害データを説明 できるモデルを構築することが重要であり、別の視点から検討した
*1 (株)日建設計構造設計部門 修士(工学)

*2 名古屋大学大学院環境学研究科教授. 工博

*3 名古屋大学大学院環境学研究科 准教授. 博士 (工学)
Structural Engineering Dept., Nikken Sekkei Ltd., M. Eng.

Prof., Grad. School of Environmental Studies, Nagoya Univ., Dr. Eng.

Assoc. Prof., Grad. School of Environmental Studies, Nagoya Univ., Dr. Eng. 
研究事例もある(例えば、長戸・川瀬ら $\left.{ }^{7}\right)$ 。

そこで本研究では、主として公営集合住宅建物を対象として、前 報)で示した中低層 RC 造学校建物と同様に、耐震診断結果に基づい て実被害を説明できる手法を構築する。まず、建物の耐力評価指標 として広く一般的に用いられている耐震診断結果と、既往の実験結 果や常時微動計測結果等を結びつけ、次にこれらを用いて、兵庫県 南部地震での集合住宅建物の被害を説明できる地震応答解析モデル を構築する。その際に、集合住宅建物の特徵を取り入れ、前報で示 した手法を改良した。

図 1 に本研究における検討フロー図を示す。低層 $\mathrm{RC}$ 造学校建物 と公営集合住宅建物の違いとして考慮した点は、(1)析行方向軸組 (雑 壁）の形状による建物の固有周期の違い、(2)柱の桁行方向に直交し て取り付く耐震壁の影響、(3)桁行方向の方立て壁の影響、である。

検討ではまず、一般的な公営集合住宅の持つ耐震性を明らかにし た上で、設計では通常考慮されない余力を考慮し、それらの諸元を 個々の耐震診断結果と関連付けることで地震応答解析モデルを構築 する。地震応答解析には等価 1 質点系のせん断型モデルを用いる。 次に、観測地震波を入力とした地震応答解析を行い、被害率の算定 を行なう。この結果と実被害と比較することで、本手法の妥当性を 検討する。

なお、兵庫県南部地震での実被害を説明するために、地震応答解 析のモデル作成時に留意した点は以下の通りである。

静的弾塑性増分解析では、(1)コンクリート強度、(2)部材のせん断 耐力、(3)積載荷重、(4)直交壁の効果、のそれぞれの設計と実状との 差、地震応答解析モデルでは、(5) $I_{s}$ 值と建物の終局耐力の関係、(6) $I_{s}$ 值と壁 (方立て壁) ・ 柱分担率の関係、(7) $I_{s}$ 值と建物の固有周期の関 係、8建物終局耐力の動的効果、被害率の算定と実被害との検証で は、(9)入力損失効果の考虑、(10被害判定のクライテリアの設定法、 (11)入地震動の方向性の考慮、である。

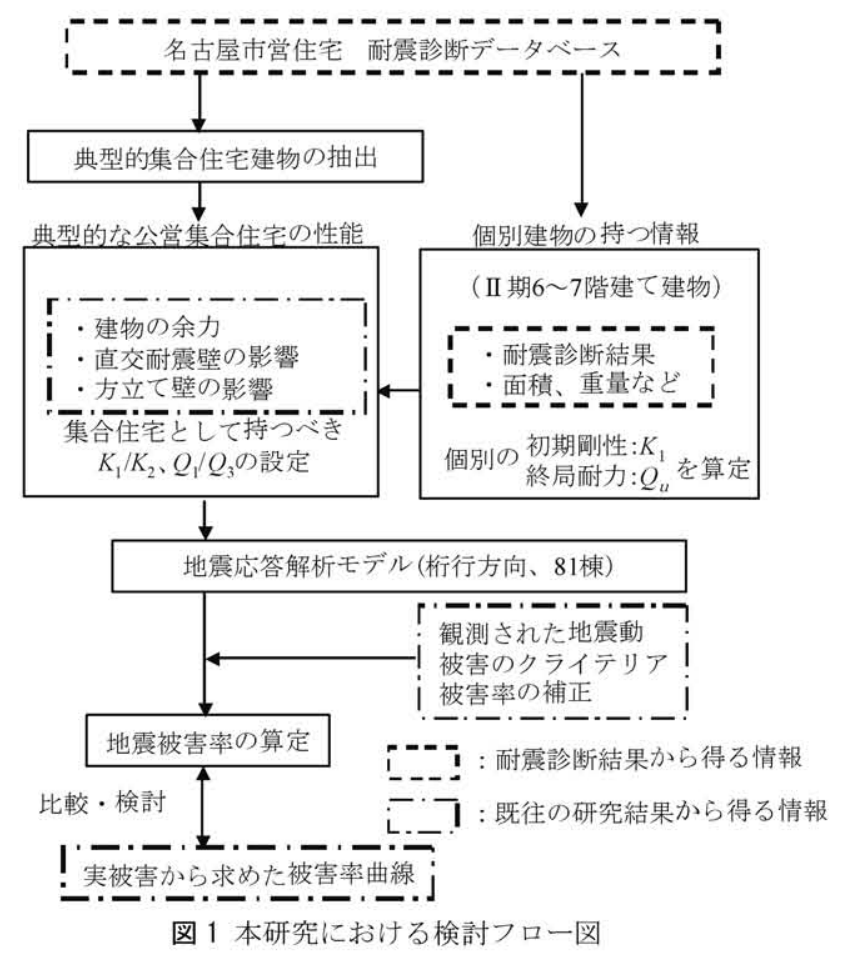

これらの留意事項について、本研究では既往の研究に基づいて、実 際の建物の平均的な特性を設定するようにつとめた。

\section{2. 耐震診断データベースの概要と典型的公営集合住宅の構造的特 徵の抽出}

\section{1 低層学校建物と公営集合住宅建物の構造的特徵の比較}

まず、前報)で対象とした低層学校建物と、本研究で対象とした 公営集合住宅建物の構造的特徵の違いを分析する。分析には、愛知 県内の学校建物を対象とした耐震診断データベース（以下学校建物 DB と略す。全 1179 棟) と名古屋市営住宅を対象とした耐震診断デー タベース（以下集合住宅 DB と略す。全 144 棟、その内 II 期 6〜7 階建ての建物は 81 棟）を用いる。

(1)而震診断データの比較

$2 つ$ 耐震診断データベースの建物階数別棟数の分布を図 2 に、 最小 $I_{s}$ 值の分布を図 3 に示寸。低層学校建物は $2 \sim 4$ 階建てが大半 を占め、その 8 割以上が新耐震基準以前の建物である。一方、集 合住宅は大半が 7 階建てで、そのうち 8 割近くが 1972 年 1981 年 (II 期)に建設されている。また、集合住宅建物は最小 $I_{s}$ 值が 0.6 未満のものがほとんどであり、耐震診断結果からみると、耐震性 能を十分に有していない建物が多いと言える。

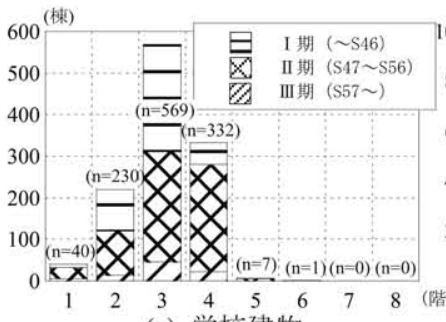

(a) 学校建物

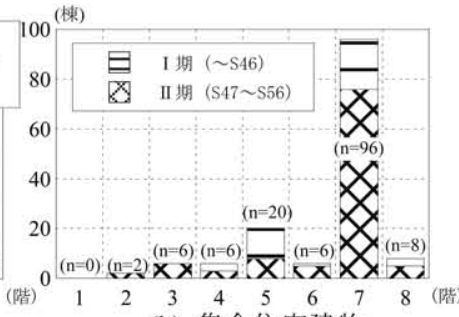

(b) 集合住宅建物
図 2 階数別棟数分布

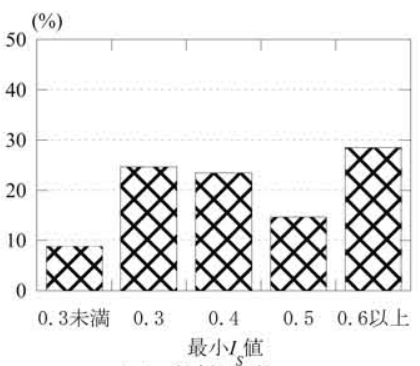

(a) 学校建物

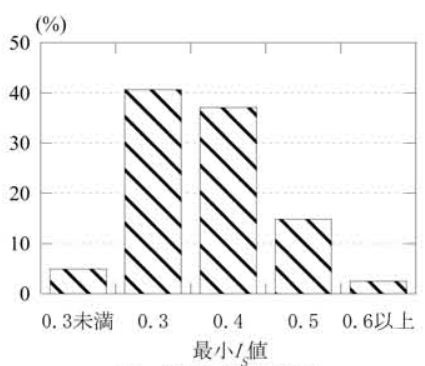

(b) 集合住宅建物
図 3 最小 $I_{s}$ 值分布

\section{(2)桁行方向の雑壁の取り付き方}

低層学校建物では北側は廊下として使用されており、腰壁と垂 壁が取り付く構造になっている゙)。これに対し、公営集合住宅建 物の北面は、玄関、浴室、台所の排煙等により様々な大きさの開 口を有しており、低層学校建物に比べて雑壁の取り付き方が複雑 になっている。一方、南面では、学校建物は腰壁のみ取り付いて いる場合が多いが、公営集合住宅建物は方立て壁が取り付き掃き 出し空となる場合が多い。南北両面ともに雑壁が複雑に取り付く ことは公営集合住宅建物の特徵である（図4の桁行方向 南北構面 軸組図を参照）。

(3)張間方向の耐震壁の取り付き方 
既往の研究で対象としている低層学校建物は、教室と廊下境に柱 を持たず、教室境の耐震壁の片端には柱が無い。これに対し公営集 合住宅建物は、廊下やベランダは片持ち形式でフレーム外に取り付 けられている場合が多いので耐震壁の両端に柱が配置されている (図4の平面図)。柱のせん断強度への直交方向の耐震壁（直交壁） の影響については、既往の研究 ${ }^{8}$ や指針9)などにも述べられている。 低層学校建物と比べて直交壁の効果をより多く見込めることは、公 営集合住宅建物の特徵と言える。

\section{2 典型的な公営集合住宅建物の構造的特徵の抽出}

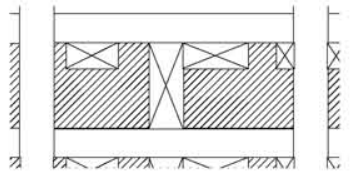

桁行方向 北構面 軸組図

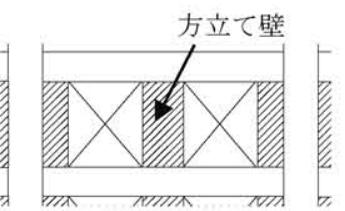

桁行方向 南構面 軸組図

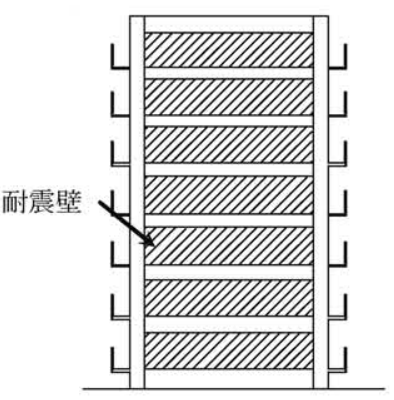

張間方向 軸組図

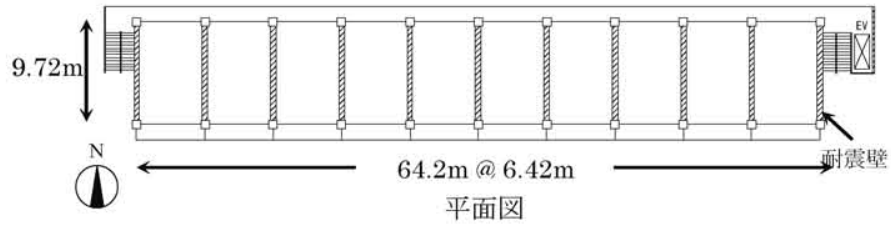

図 4 典型的な集合住宅の平面図と軸組図

集合住宅 DB 内の建物のうち、7 階建て建物の中から任意に 26 棟を選び詳細な図面調査を行なった。2 6 棟のうち構造スリットを有 する建物は 1 棟のみ存在し、1 階にピロティを有するものは無い。 図面調査より抽出した典型的な公営集合住宅建物の略図を図 4 に示 す。建物の主な諸元は、桁行 10 スパン×張間 1 スパン、階高は 1 階 が $2.8 \mathrm{~m}$ で 2 階以上は $2.6 \mathrm{~m}$ 、南北構面に開口付き雑壁が存在し、バ ルコニーと廊下は片持ち形式となっている。これらは、神戸市と名 古屋市の公営集合住宅の図面を比較した限りでは、公営集合住宅建 物に共通する特徴と考えられる。

本研究では、地震時に被害の生じやすいと考えられる建物の桁行 方向について検討を行う。

\section{3. 一般的な公営集合住宅建物の性能}

一般的な公営集合住宅建物の復元力モデルを設定するために、2 節で抽出した典型的な公営集合住宅建物を対象として、部材モデル を用いた弾塑性立体骨組解析モデルを作成し、このモデルを用いた 静的増分解析を行う。静的弾塑性解析時の荷重分布形は $\mathrm{Ai}$ 分布を基 本とし、上層部で終局に達しない場合は、別途上層で終局状態に達 するように分布形を変更し、該当する階の終局耐力を算定する。得 られた層間変形一層せん断力関係は、通常の設計で用いられている ように、復元力の耐力低下を考慮しない Tri-Linear 型の復元力特性 （図 5）で近似する。静的弾塑性解増分析結果に基づく復元力特性 の設定方法は以下の通りである。
·第 1 折点: 各層のいずれかの部材でクラックが発生する点とする。 ・第 2 折点 : 各層のいずれかの部材が降伏したときの層間変形で、 静的弾塑性解析結果と Tri-Linear 型モデルの面積が等 しくなる層せん断力となる点（図 5）とする。

・第 3 折点 : 層間変形角が $1 / 75$ となる点。ここで、第 3 折点は終局 耐力を意味し、建物の被害 (大破) のクライテリア (後 述）を参考に設定する。

静的弾塑性解析モデルは、袖壁や雑壁の耐力、及び建物の余力を 考慮しない一般設計モデル【TypeA】と、建物の実状を反映するた めに、南構面の袖壁や北構面の雑壁の耐力、及び建物の余力を考慮 した余力考慮モデル【TypeB】の 2 種類とする。ここで、建物の 余力とは、一般的な構造設計では安全側となるように考慮してい ないが、実際の剛性や耐力には寄与していると考えられる項目 (本 論では、1 節の(1)〜 (4)) を示す。以降では、それぞれのモデル化 方法について述べる。

なお、現実には大 変形領域では耐力低 下が起こるため、最 大耐力（終局耐力） 後の挙動を実状に則 してモデル化する必 要がある。これにつ いては 4.2 項で詳細 に述べる。

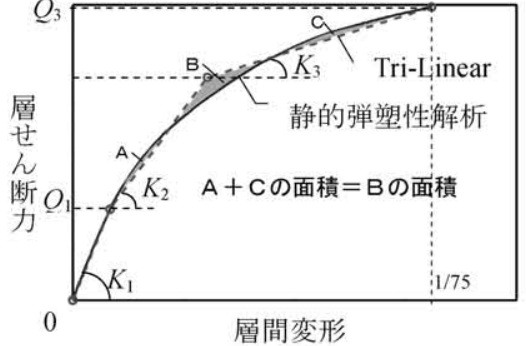

図 5 復元力特性

\section{1 雑壁のモデル化}

建物の実状をモデルに考慮するために、桁行方向北構面の雑壁 を、図 6 のように壁柱・袖壁・腰壁に、南構面の雑壁も同様に壁 柱・袖壁に置換し、剛性と耐力を評価する。また、壁柱と柱の柱頭 に雑壁などを考慮した剛域を設けた。

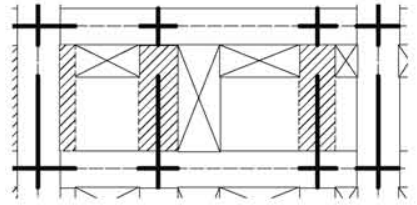

袖壁、壁柱として評価する部分

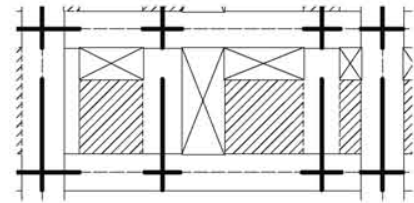

腰壁付梁として評価する部分

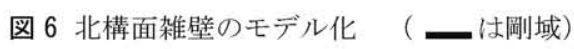

\section{2 建物の余力}

TypeB では建物の余力として以下の 4 項目を考慮する。 (1)設計に用いるコンクリート強度と実際の強度の違い

集合住宅 DB 中の、今回対象とした建物のコンクリート設計基 淮強度は、大半が $F c=210\left(\mathrm{~kg} / \mathrm{cm}^{2}\right)$ であった。一方、既往の研究 ${ }^{10)}$ によると、1981 年以前の京阪神地区の公共建物では $F c=210$ $\left(\mathrm{kg} / \mathrm{cm}^{2}\right)$ のものは、コアコンクリートの圧縮試験により実際に は $F c=300\left(\mathrm{~kg} / \mathrm{cm}^{2}\right)$ 程度あることが明らかにされているため、こ の值を採用する。

(2)設計に用いる $\mathrm{RC}$ 部材のせん断耐力とその平均的なせん断耐力と の違い

一般の設計 (2007 年施行の改正建築基準法以前に設計された建 物や耐震診断が実施された建物）では、梁のせん断耐力式として 
下式を用いている。

$$
Q_{u}=\left\{\frac{0.053 p_{t}^{0.23}(F c+180)}{M /(Q \cdot d)+0.12}+2.7 \sqrt{p_{w} \cdot \sigma_{w y}}\right\} b_{e} \cdot j
$$

ここで、 $Q_{u}$ : 部材のせん断耐力 $(\mathrm{kg}) 、 p_{t}, p_{w}$ : 引張鉄筋比 $(\%)$, せん断補強筋比、 $F_{C}$ : コンクリート圧縮強度 $\left(\mathrm{kg} / \mathrm{cm}^{2}\right) 、 M / Q:$ 曲 げモーメント $M$ とせん断力 $Q$ の比（ただし $1 \leqq M / Q d \leqq 3 ） 、 d:$ 梁 の有効せい $(\mathrm{cm}) 、 \sigma_{w y}$ : せん断補強筋の降伏点強度 $\left(\mathrm{kg} / \mathrm{cm}^{2}\right)$ 、 $b_{e}:$ 梁幅 $(\mathrm{cm}) 、 j:$ 応力中心距離 $(\mathrm{cm})$ である。

この式は実験結果の平均值ではなく、安全側に評価した下限値 だと考えられる。そこで、実験結果の平均的な評価となるように (1)式の第 1 項の係数 0.053 を 0.068 とする ${ }^{11)}$ 。柱、壁についても 同様に、平均的な評価となる式を用いてせん断耐力を評価する。

(3)設計に用いる積載荷重と実際の積載荷重の違い

設計では建築基淮法・同施行令や 指針などに定められた值を用いるが、 ここでは実状を反映した積載荷重と して表 1 に示す值を用いる。後に示 す地震応答解析モデル構築の際にも

この積載荷重を用いる。

表 1 積載荷重

\begin{tabular}{|c|c|c|}
\hline 用途 & 指針など & 実状を考虑 \\
\hline 住宅 & & \\
\hline 廊下 & 600 & 300 \\
\hline 階段室 & & \\
\hline 屋根 & 400 & 0 \\
\hline
\end{tabular}

(4)直交壁によるせん断耐力の上昇

今回対象とした集合住宅では、桁行方向の柱に直交する連層耐 震壁があるので、直交壁が終局耐力に与える影響を考慮する。既 往の設計施工指針 ${ }^{9}$ などを参考にして、直交壁による強度上昇と して柱のせん断耐力を 1.3 倍とする。

なお建物の余力は上記以外の要因も考えられるが、本研究では上 記のみを考慮する。

\section{3 建物の余力の影響}

表 2 に、一般設計モデル（TypeA）と余力考慮モデル（TypeB）の 静的弾塑性解析結果の比較を示す。初期剛性の比は 9.95 倍、終局耐 力の比は 2.42 倍になった。初期剛性 $K_{1}$ は主に雑壁を考慮した影響、 終局耐力 $Q_{3}$ は雑壁及び建物の余力を考慮した影響だと考えられる。

表 2 TypeA と TypeB の比較

\begin{tabular}{cccccc}
\hline & $K_{1}$ の比 & $Q_{3}$ の比 & $C$ の比 & $T$ の比 & $\Sigma W$ の比 \\
\hline TypeB/TypeA & 9.95 & 2.42 & 2.51 & 0.32 & 0.96 \\
\hline$C:$ 終局層せん断力係数 $T$ : 固有周期 (弾性時) & $\Sigma W:$ 建物の総重量
\end{tabular}

TypeA と TypeB とでは、初 期剛性と終局耐力に大きな 違いがあることがわかり、 このことから一般設計モデ ルでは建物の耐震性能を相 当に安全側に評価している 可能性があると考えられる。

\section{4 方立て壁の分離}

集合住宅建物の地震被害 の特徴として、方立て壁の 剛性が高く、ラーメン構造 に比べ層間変形角が小さい 領域で脆性的なせん断破壊 が起こるため、主フレーム

表 3 静的弹塑性解析結果

\begin{tabular}{ccc}
\hline & $K_{2} / \mathrm{K}_{1}$ & $Q_{3} / Q_{1}$ \\
\hline 方立て壁部分 & 0.527 & 2.965 \\
主フレーム部分 & 0.505 & 5.235 \\
\hline
\end{tabular}

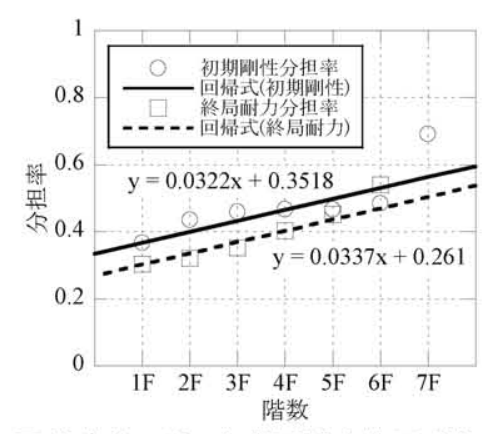

図 7 方立て壁の初期剛性と終局耐力 の分担率とその回帰式
に先行して方立て壁がせん断破壊することが挙げられる ${ }^{12)}$ これを 表現できるモデルにするために、方立て壁部分と主フレーム部分に 異なる耐震性能を持たせる。静的弾塑性解析時に建物全体で負担す るせん断力を、方立て壁部分と主フレーム部分が負担するせん断力 に分離し、それぞれについて骨格曲線を定義する。それぞれの静的 弾塑性解析結果を表 3 に示す。

建物の復元力特性を作成する際には、分離した骨格曲線の初期剛 性 $\left(K_{1}\right)$ および終局耐力 $\left(Q_{3}\right)$ の比を用いて、各階の $K_{1}$ およひ $Q_{3}$ を方立て壁部分と主フレーム部分に分配する。方立て壁の初期剛性 と終局耐力の分担率を算定した結果を図 7 に示す。最上階では、方 立て壁架構のせん断力分担率が $100 \%$ を越え、ラーメン架構のせん 断力の負担方向が加力方向と逆になる、いわゆる逆せん断力現象が 見られる (図 7 では図の枠外に位置するので省略している)。本研究 では、地震時に被害の発生し易い下層(1 4 階)の分担率の值から回 帰式を求め、その回帰式を用いて、方立て壁の初期剛性と終局耐力 の分担率を算定する（図 7)。

\section{4. 地震応答解析モデルの構築 \\ 4.1 建物の固有周期の設定}

低層 RC 造建物については、最小 $I_{S}$ 値と固有周期係数 $\alpha(=T / h$ 、 $T:$ 建物の 1 次固有周期 (秒)、 $h:$ 建物高さ $(\mathrm{m}))$ に相関関係があ ることが明らかになってい る ${ }^{13)}$ 。そこで、集合住宅 DB 中の最小 $I_{S}$ 值の異なる集合 住宅建物 6 棟（表 4）を対 象に林行方向を対象に常時 微動計測を行い、最小 $I_{S}$ 值 と固有周期係数の関係を調 ベた。常時微動計測を行う 建物を選定する際、表層地 盤特性の建物間の違いを取 り除く様に選定した。具体

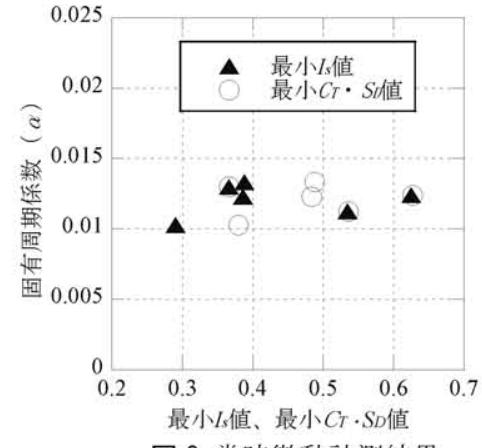

図 8 常時微動計測結果 的には、表層地盤の増幅特性を簡易的にあらわすために考案された 表層 $30 \mathrm{~m}$ のせん断波速度の平均値 $A V S 30^{14)}$ の值がほぼ等しい $(A V S 30$ $\doteqdot 200 \mathrm{~m} / \mathrm{s}$ ）場所に建つ建物を対象とした。結果を図 8 に示す。集合 住宅建物において、最小 $I_{S}$ 値と固有周期係数に相関はほとんど無く、 全建物で固有周期係数が $0.01 \sim 0.015$ という結果になった。

また、最小 $C_{T} \cdot S_{D}$ 值でも同様の傾向が見られる。これは、集合住 宅の桁行方向軸組図（雑壁の形状）がほぼ同じで、それに加え、こ の雑壁が建物の初期剛性に与える影響が大きいため、 $I_{S}$ 值に関わら ず建物の固有周期係数は一定となり、固有周期は建物の高さに比例

表 4 常時微動計測対象建物一覧表

\begin{tabular}{ccccc}
\hline & 階数 & 最小 $I_{s}$ 值 & 最小 $C_{T} \cdot S_{D}$ 値 & 竣工年 \\
\hline 建物 $\mathrm{A}$ & 7 & 0.290 & 0.380 & 昭和 49 年 \\
建物 $\mathrm{B}$ & 7 & 0.366 & 0.367 & 昭和 53 年 \\
建物 $\mathrm{C}$ & 7 & 0.388 & 0.488 & 昭和 53 年 \\
建物 $\mathrm{D}$ & 7 & 0.535 & 0.536 & 昭和51年 \\
建物 $\mathrm{E}$ & 4 & 0.625 & 0.627 & 昭和 54 年 \\
建物 $\mathrm{F}$ & 7 & 0.386 & 0.484 & 昭和 52 年 \\
\hline
\end{tabular}




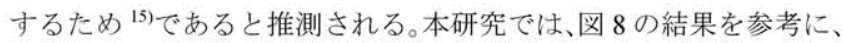
固有周期係数 : $\alpha=0.0125$ として地震応答解析モデルの固有周期を 決定する。

\section{2 地震応答解析モデル構築手順}

集合住宅 DB のうち、本節で対象としている建物は、全て 1981 年以前に設計されている。1981 年以前の R C 造建物は、一般に大変 形時に耐力低下を起こす柱崩壊型となるとされている ${ }^{16)}$ 。そこで、 既往の実験結果 ${ }^{16)}$ を参考に、大弯形時の耐力低下を考慮した復元力 特性を設定する。具体的には、図 9 に示すように、崩壊点(終点)を 決定し、第 2 折点(終局耐力時) と崩壊点とを結ぶように第 3 勾配を 決定する。崩壊点の層間変形角: $\theta$ は、主フレーム部分は $\theta=1 / 29^{16)}$ 、 方立て壁部分は $\theta=1 / 80^{12)}$ とし、その時の層せん断力はともに $0 \mathrm{kN}$ の 点とする。なお、 $P$ - $\Delta$ 奮の復元力特性に与える影響については、 既往の実験結果 ${ }^{16}$ が、柱軸力と大変形を考慮しているため、耐力低 下を考慮した復元力特性設定時に考慮されていると考え、本研究で は考慮しない。また、余力考慮モデルには、3.2 項に示した 4 点に 加え、終局耐力のひずみ 速度依存性を考慮する。 壁や柱を対象とした既往 の研究 ${ }^{17) 18)}$ によれば、建 物の終局耐力に与える動 的効果は 1.1 倍以上ある ので、ここでは終局耐力 を 1.1 倍する。 表 5 に、地震応答解析

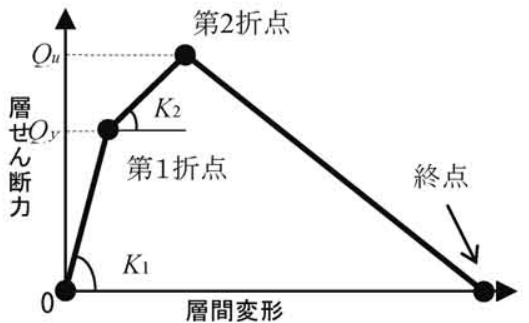

図 9 耐力低下を考慮した復元力特性 モデル作成の際に用いた主たる仮定条件を示す。このうち、集合住 宅 DB から建物毎に值を設定したのは、 $A$ : 延床面積、 $n$ : 建物階数、 $C_{T} \cdot S_{D}$ : 各階 $C_{T} \cdot S_{D}$ 值、 $S_{D}$ 值 : 各階 $S_{D}$ 值である。また、階の平均 単位面積重量 $W$ は、図 4 で示した代表的な建物の重量について、仕 上げ等を考虑して算定した数值を用いた。これらの值を用いて復元 力特性を建物毎に設定する。

地震応答解析モデルの具体的な作成手順は、

(1)集合住宅 DB の延床面積から、各階等面積として各階重量を計算 する。

(2)固有周期係数 $\alpha=0.0125$ として 1 次

固有周期を算定する。

(3)各階 $C_{T} \cdot S_{D}$ 值から(2)式及び荷重速 度の影響を考慮し、一体モデルの各 階終局せん断耐力を求める。ただし、 図 9 に示すように大変形時の耐力低 下を考慮するため、算定した終局耐 力は第 2 折点の耐力とする。

$C_{i}=\left(C_{T} \cdot S_{D}\right) \cdot(n+i) /(n+1) / S_{D}$

$C_{i}: i$ 階の終局せん断耐力係数

$i:$ 階数 、 $n:$ 建物階数

(4)各階重量と固有周期から各階初期剛 性を求める。剛性の高さ方向分布は、 各階の終局耐力と相似形にする。 (5)各階の $K_{1}$ および $Q_{u}$ を方立て壁部分
とフレーム部分に分配し、そ れぞれについて静的弾塑性解 析結果（表 3）の、 $K_{2} / K_{1}$ お び $Q_{1} / Q_{2}$ を用いて復元力特性 を作成する。この際に、大変 形時の耐力低下を考慮する (図 9)。履歴特性は、方立て 壁部分は原点指向型モデル、 主フレーム部分は修正武田ス リップモデル19) (図 10) とす る。修正武田スリップモデル

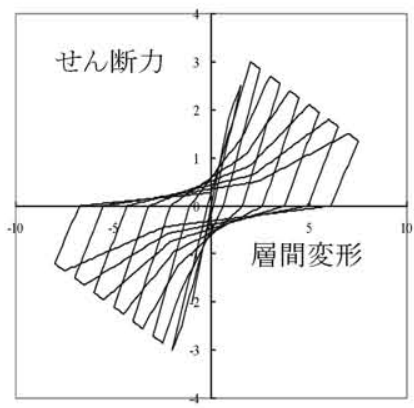

図 10 修正武田スリップ モデルの履歴特性
は、1981 年頃以前に建設された既存 RC 建物に多いせん断破壊型 の柱の履歴特性と実験結果で対応が良い。その特徵は、武田スリ ップモデル ${ }^{20)}$ と比べると、せん断破壊が生じ耐力が低下しその後 加力方向が反転した時に、せん断破壊が起こった方向での最大変 形の原点に対して対象となる点を指向することである。

(6)半無限一様地盤上の円形剛

基礎の静的ばねと波動インピーダンスから算定した減衰係数を用 いスウェイ・ロッキングばねを考慮する ${ }^{2122)}$ ささらに、スウェイ・ ロッキングばねの算定時には、基礎のアスペクト比による補正 ${ }^{23)}$ を行い、矩形剛基礎のばねとして、これを算定する。なお、学校 建物等の常時微動計測の経験により、スウェイについては剛基礎 と考えられる。また、ロッキングについては、桁行方向は剛基礎 とは言い難いが、もともとロッキング動は顕著ではなく、スウェ イが卓越するため、剛基礎と考えてモデル化を行っても問題は無 いと考えられる。また、基礎重量は平均単位面積重量に建物面積 をかけて求め、回転慣性は(3)式により求めている。その際、基礎 の高さは 0 として算定している。なお、地震波はロッキングばね 下部に入力する。上部構造の減衰は、剛性が負の領域を含むので 初期剛性比例(基礎固定時の初期剛性に比例)として $3 \%$ とする。

$$
I_{x}=\frac{m}{12}\left(a^{2}+b^{2}\right)
$$

$m$ : 基礎質量

$a:$ 桁行方向建物長さ、 $b$ : 基伥高さ ( 0 として算定)

表 5 本研究で用いた仮定値

\begin{tabular}{|c|c|c|c|}
\hline 算定するもの & 用いた仮定・算定式 & 必要な仮定値 & 本研究で用いた值 \\
\hline \multirow{2}{*}{ 各階の階高 $(h i)$} & & 2階以上の階高 $\left(h_{1}\right)$ & $2.60 \mathrm{~m}$ \\
\hline & & 1階の階高 $\left(h_{0}\right)$ & $2.80 \mathrm{~m}$ \\
\hline 各階床面積 $(A i)$ & $A_{i}=A / n$ & 延床面積 $(A)$ 、階数 $(n)$ & 各建物別に設定 \\
\hline 建物の長辺長さ $\left(B_{L}\right)$ & $B_{L}=A_{i} / C_{L}$ & 建物の短辺の長さ $\left(C_{L}\right)$ & $9.72 \mathrm{~m}$ \\
\hline 各階重量 $(W i)$ & $W_{i}=A i \cdot W$ & $\begin{array}{l}\text { 階の平均単位面積重量 }(W) \\
\end{array}$ & $10.7 \mathrm{kN} / \mathrm{m}^{2}$ \\
\hline 建物の1次固有周期 $\left(T_{1}\right)$ & $T_{1}=\alpha \cdot h$ & 固有周期係数 $(\alpha)$ & $a=0.0125$ \\
\hline \multirow{2}{*}{ 各階の初期剛性 $\left(K{ }^{1} i\right)$} & 初期剛性の高さ方向分布は & 建物の1次固有周期 $(T 1)$ & \\
\hline & 各階の終局耐力分布に相似 & 各階重量 $\left(W_{i}\right)$ & \\
\hline \multirow{2}{*}{ 各階の第2剛性 $\left(K_{2 i}\right)$} & \multirow{2}{*}{$K_{2 i}=K_{1 i} \cdot K_{2} / K_{1}$} & 方立て壁 : $K_{2} / K_{1}$ & 0.527 \\
\hline & & 主フレーム $: K_{2} / K_{1}$ & 0.505 \\
\hline \multirow{2}{*}{$\begin{array}{l}\text { 各階の終局耐力 }\left(Q_{u i}\right) \\
\text { (第2折点層せん断力 })\end{array}$} & $Q_{u i}=\Sigma W i \cdot C_{T} \cdot S_{D} i \cdot(n+i)$ & $\mathrm{S}_{\mathrm{D}}$ 值 $\left(S_{D}\right)$ & 各建物別に設定 \\
\hline & $/(n+1) / S_{D}$ & 各階 $C_{T} \cdot S_{D}$ 値 $\left(C_{T} \cdot S_{D}\right)$ & 各建物別に設定 \\
\hline \multirow{2}{*}{ 建物の第1折点層せん断力 $\left(Q_{y i}\right)$} & \multirow{2}{*}{$Q_{y i}=Q_{u i} \cdot Q_{1} / Q_{3}$} & 方立て壁: $Q_{1 / Q^{3}}$ & 0.337 \\
\hline & & フレーム: $Q_{1} / Q_{3}$ & 0.191 \\
\hline \multirow{3}{*}{ 地盤ばね } & & せん断波速度 $(V s)$ & $250 \mathrm{~m} / \mathrm{s}$ \\
\hline & & 単位体積重量 $(\rho)$ & $1.8 \mathrm{t} / \mathrm{m}^{3}$ \\
\hline & & ポアソン比 $(\nu)$ & 0.45 \\
\hline
\end{tabular}




\section{5. 兵庫県南部地震の実被害との比較}

\section{1 被害のクライテリアの設定}

地震応答解析結果から被害率を算定する際には、下式を用いる。

$$
\begin{gathered}
\text { 被害率 }=\frac{\theta か ゙ \text { 被害のクライテリアを超えた建物棟数 }}{\text { 全建物棟数 }} \times 100(\%) \\
\theta: \text { 最大層間変形角 }
\end{gathered}
$$

上式を用いる際には、中破、大破といった被害程度毎に最大層間 変形角 $(\theta)$ のクライテリアを設定する必要がある。大破や中破の クライテリアの設定には様々な議論があるが、本研究では、過去の 被害状況から推定された、既往の研究 ${ }^{24)}$ を参考に、以下のクライテ リアを用いることとする。

$$
\begin{aligned}
& \text { 中破以上: } 1 / 150<\theta \\
& \text { 大破 } \quad \text { : } 1 / 75<\theta
\end{aligned}
$$

\section{2 入力地震動の方向性による補正}

図 11 に兵庫県南部地震における 8 12 階建て $\mathrm{RC}$ 造建物の桁行の 方位と被害率の関係 ${ }^{25}$ を示す。図の半径方向が建物の析行方向、各 軸の大きさは被害率、( )内は全棟数を表している。図より、建物 の方向による被害の差は明らかであるので、本研究では図 11 に基づ いて地震応答解析から算定した被害率を補正する。例えば桁行方向 がN090E の建物の場合については、下式により補正を行なう。ここ でN090E とは、北から時計回りに $90^{\circ}$ 回転した方向を表している。

\section{桁行N $090 E$ 方向の計算被害率 $\times \frac{\text { 図11の全方向の被害率 }}{\text { 図 }}$}

被害率は、棟数が多く、方向による差が明確な中破のデータを用い て補正する。この入力地震動の方向による補正を、補正方法 $N 090 E$ と呼ぶ。同様に $N 000 E$ 方向の地震動が建物の桁行方向に入力し、被 害率を算定した結果に対して、

入力地震動の方向性による補正 を行った建物の被害率を、補正 方法 $N 000 E$ と呼ぶ。いずれの補 正方法でも、入力地震動の最大 速度は、図 11 から地震動の主軸 方向と推定される N315E 成分 の最大速度で定義し、 $80 \mathrm{~cm} / \mathrm{s}$ か ら $150 \mathrm{~cm} / \mathrm{s}$ まで $10 \mathrm{~cm} / \mathrm{s}$ 毎に被害 率を求める。その際、入力損失 効果を考慮し、入力地震動の加 速度の大きさを 0.9 倍する 26 。

\section{3 地震応答解析結果と被害}

\section{率曲線の比較}

地震応答解析に用いた入力地 震動は兵庫県南部地震において 甚大な被害を受けた地域で観測 された JR 鷹取駅 ${ }^{27}$ (以下、JR 鷹取) および大阪ガス莫合波(以 下、大阪ガス莫合）を用いる。 なお、神戸海洋気象台の地震波 は、観測点が高台に位置してい
るため、局所的な地形変化の影響を受けており ${ }^{28)}$ 、高台の周辺の建 物被害を十分に説明できるものではないと考え、検討には用いなか った。また、入力地震動の方向は、RC 造 8〜12 階建てを対象とし た兵庫県南部地震での実建物の被害率 ${ }^{25}$ において、建物数の多い方 向となる $N 090 E$ および $N 000 E$ 方向（図 11）の地震動が、建物の桁 行に入力する場合について検討を行う。なお、被害率曲線を作成さ れる時に用いられた建物で最も多い用途は集合住宅建物であるため、 本研究では、建物用途による補正は行わなかった。

余力考慮モデルを用いた地震応答解析結果に基づいて計算した被 害率 (計算被害率と呼ぶ) と、兵庫県南部地震での被害率曲線 ${ }^{25}$ ) (実 被害率と呼ぶ）を比較して図 12 に示す。図中、入力地震動別（JR 鷹取と大阪ガス莫合）および入力地震動の方向による補正方法別 （5.2 項参照）に結果を示している。また、比較に用いた被害率曲 線は、【期に建設された 6 7 階建て建物(ピロティなし)を対象とし たものなので、本研究で述べてきた手法を用いて集合住宅 DB 中の II 期 6 7 階建て建物 81 棟のモデルを作成し、地震応答解析を行な った。

図 12 より、JR 鷹取を入力地 震動とした場合の、補正方法 $N O 90 E$ および補正方法 $N O 00 E$ で は計算被害率の方が実被害率に 比べ大きいが、その他について は、計算被害率と実被害率は概 ね対応しているといえる。とく に、大阪ガス蕞合を入力した場 合の補正方法 $N 090 E$ や $N 000 E$ では、よく対応している。また、 補正方法 $N 090 E$ で、入力地震動
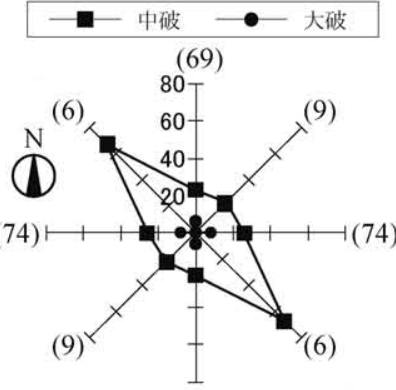

(69)

図 $11 \mathrm{RC}$ 造建物の桁行の方位 と被害の関係 ${ }^{25)}$
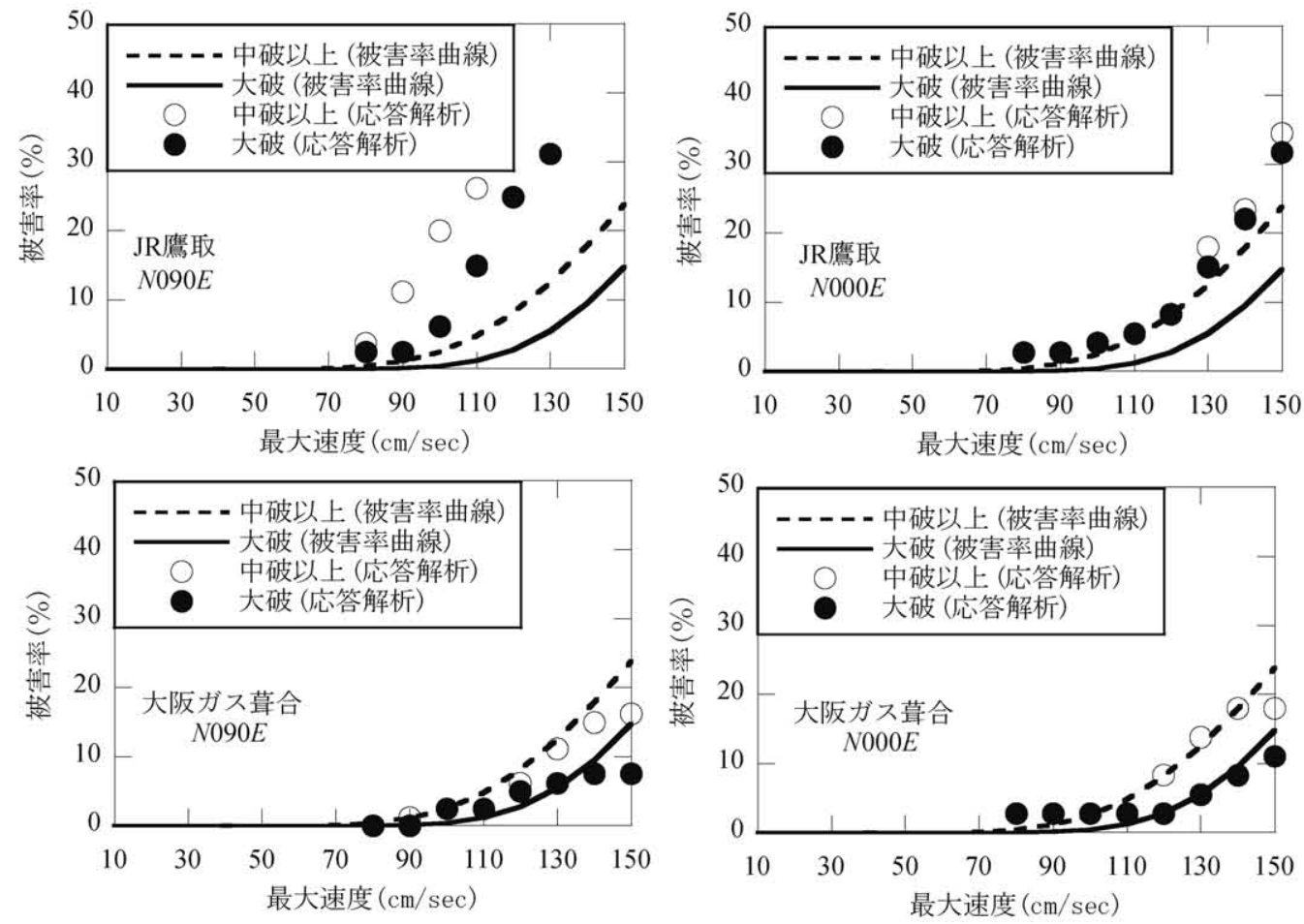

図 12 余力考慮モデルによる計算被害率と被害率曲線の比較 
によって計算被害率と実被害率の対応が大きく異なっている。これ は、JR 鷹取と大阪ガス莫合では地震動の主軸方向が異なっているこ とが原因していると考えられる4)。図 11 に示した被害率曲線の算定 に用いたデータは神戸市灘区・東灘区のデータであり、両地区に近 い大阪ガス莫合で得られた記録を入力地震動とした場合に被害率が 良く対応したと考えられる。一方、JR鷹取については、同観測点周 辺で同様な被害データが得られていないため、大阪ガス莫合観測点 周辺の結果を代用したことにより、大阪ガス蕞合に比べて対応が良 くなかったと考えられる。

以上の考察の結果、兵庫県南部地震における計算被害率と実被害 率は概ね対応しており、本研究で作成した地震応答解析モデルは妥 当であると考えられる。

\section{4 余力の影響}

大阪ガス草合波 N $090 E$ 方向を入力した際の余力の有無による計 算被害率の違いを図 13 に示す。このとき、入力地震動の方向による 補正は行っていない。例えば最大速度 $120 \mathrm{~cm} / \mathrm{s}$ で中破以上の場合、 被害率を比較すると、両者には約 3 倍の差がある。また、入力地震 動の最大速度が大きくなると、さらに両者の差は開く。これより、 設計時に考慮していない建物の余力が、兵庫県南部地震において鉄 筋コンクリート造建物の被害が設計時の想定よりも少なかった理由 の一つとして考えることができる。また、本研究で考慮したそれぞ れの余力が、計算被害率にどの程度影響を与えているのかを検討す るために、地震応答解析モデルから建物の余力の項目を一つ取り除 いた際の計算被害率(N090E 方向、中破以上)の比較を行なった。結 果を表 6 に示す。これらより、コンクリート強度に加え、集合住宅 建物の特徴である直交壁効果が、被害率に最も影響を与えている項 目であることがわかる。

直交壁効果は、多くの居室境に壁が入っている集合住宅建物で特 徵的な建物の余力であるが、耐震診断では、第 2 種構造要素の判定 以外で直交壁の効果は考慮されておらず、このことが集合住宅建物 において、耐震診断結果が実耐力を小さめに評価している原因の一 つであると考えられる。

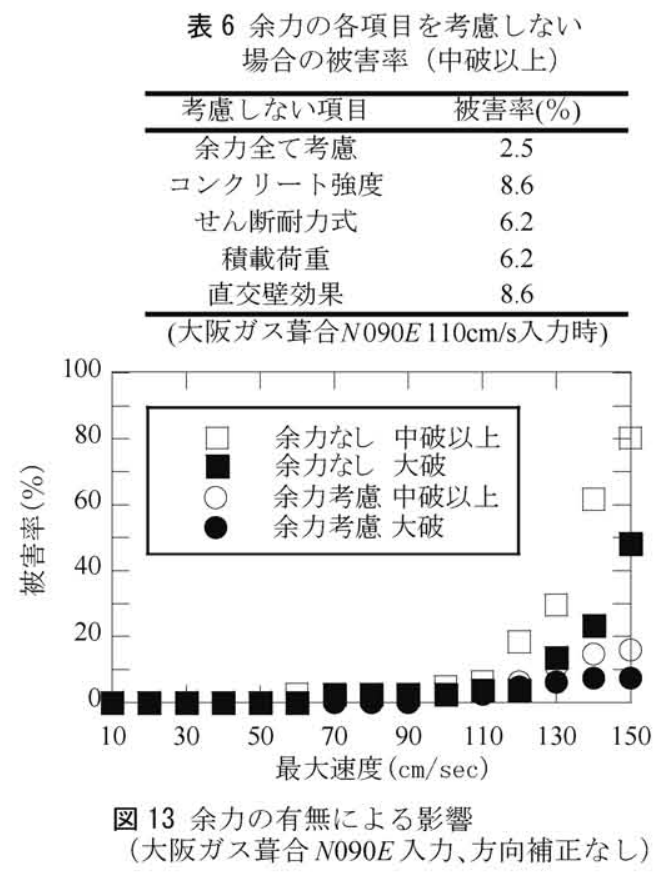

\section{5 構造スリットの有無が被害率に与える影響}

近年、集合住宅建物のように、雑壁などの 2 次部材が多く取り付 く鉄筋コンクリート造の建物では、柱の短柱化によるせん断破壊を 避けるため（せん断破壊を避けることで建物の構造設計 (二次設計) 時に、必要保有耐力を設定する際に必要な構造特性係数 : Ds を小さ く設定していることになる。)や、偏心率や剛性率の算定を容易にす るためなどの理由で、構造スリットが用いられることが多い。そこ で、3 節で示した典型的集合住宅建物に構造スリットを設けた場合、 大阪ガス莫合波に対する計算被害率や応答結果がどの程度変化する かを検討する。

スリットモデルを作成する際、図 14 に示すように、典型的建物の 南北構面に三方向完全スリットを設ける。雑壁は、上階の梁を垂れ 壁付き梁として剛性を評価し、雑壁による終局耐力への影響は考慮 しない。構造スリット無し建物の固有周期は、桁行方向が各階とも ほぼ同じ軸組（バルコニー側および廊下側の雑壁の形状）となって いるため、初期剛性に雑壁が与える影響が大きいと考えられる (4.1 項)。それに比べるとスリットを設けた建物は、この雑壁が与える影 響は大きくないと考えられる。そこで、既往の研究 ${ }^{13)}$ を参考にして、 初期剛性は、建物の最小 $I_{s}$ 值に関係すると仮定する。具体的には、 低層学校建物を対象とした最小 $I_{s}$ 值と固有周期係数の関係 ${ }^{4)}$ を用い て、初期剛性を算定した。しかし、この関係は低層建物を対象とし ており、これを本研究では 6〜 7 階建て建物に適用するため、その精 度はやや落ちると考えられる。地震応答解析に用いる復元力モデル は、典型的な建物モデル（2.2 項）に、構造スリットを設けた弾塑 性立体骨組解析モデルを用いて、増分解析を行ない設定した。その 手順は構造スリットがない建物の場合 (4.2 項) と同様である。履 歴特性は武田スリップモデルを用い、終局点は層間変形角 $\theta=1 / 29^{16)}$ 、 層せん断力 $0 \mathrm{kN}$ の点とする。また、被害のクライテリアは、構造ス リットの有無に関わりなく、(4)、(5)式を採用する。なお、構造スリ ットを設けると柱の勒性が改善されるため、本来であれば、被害の クライテリアは、構造スリットを設けない場合とは異なると考えら れる。これについては、今後の課題としたい。

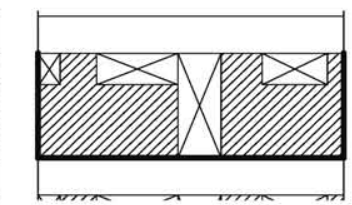

b) 北側構面

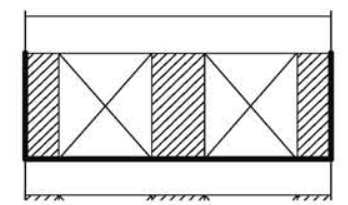

a) 南側構面 図 14 三方向スリットの概要(一構造スリット)

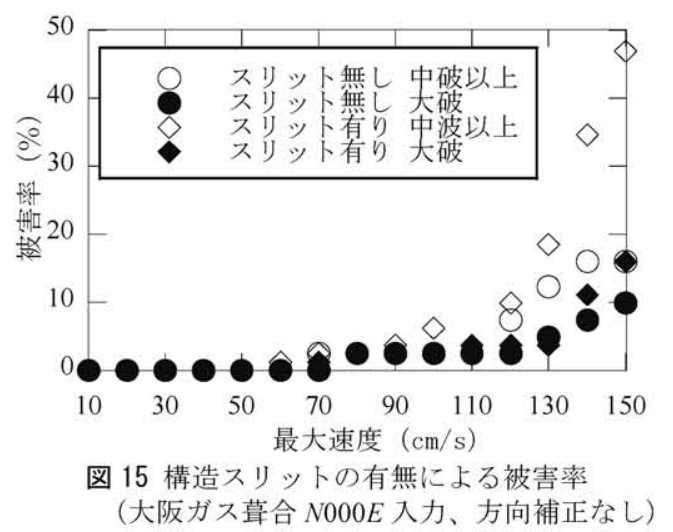


スリットの有無による地震被害率の差を図 15 に示す。スリット無 しモデルの被害率と比較すると、スリット有りモデルは建物の余力 を考慮しているにもかかわらず、入力地震動の最大速度が大きくな るに従い、被害率はより大きくなる。例えば、最大速度 $120 \mathrm{~cm} / \mathrm{s}$ で 大破の場合、両者の被害率の差は約 1.5 倍となっている。これは、 スリット有りの場合、建物の初期剛性および而力が、より小さくな っているためだと考えられる。

\section{6. まとめ}

一般的に用いられている耐震診断の結果と、実験結果等を結びつ けることで、公営集合住宅建物の地震被害を説明できる地震応答解 析モデルを構築した。その際、公営集合住宅特有の構造的特徵をモ デルに与え、既存の方法とは異なる特性を持つモデルを構筑し、兵 庫県南部地震の建物被害を説明できることを示した。

本研究で構築したモデルを用いた地震応答計算により、兵庫県南 部地震において、設計では無視している2 次部材の影響や、設計で 考慮しない建物の余力の有無により、建物の被害率が、大阪ガス莫 合波 $N 000 E(120 \mathrm{~cm} / \mathrm{s})$ 入力で中破の場合、両者の差は約 3 倍あり、 入力地震地震動の最大速度がより大きくなると、両者の差は更に開 くことを示した。これは、建物の余力があったために、想定した被 害よりも実被害が少なかったためと考えられる。これら建物の余力 は、耐震診断にも反映されていない事項もあり、耐震診断結果は建 物の実耐力を小さめに評価している可能性がある。

全国各地で実施されている公営集合住宅の耐震診断結果を基に、 本研究で構築した地震応答解析モデルを作成し、最近精力的に行わ れているシナリオ型地震の強震動予測結果を組み合わせることによ り、地域固有の地震環境亡建物固有の耐震性能に基づく、より精度 の高い建物の被害予測が可能になる。これにより、耐震診断結果の 具体的な被災状況を説明することが出来るため、耐震診断結果の説 明性が増し、耐震補強を促進することの一助になると考える。

また、本研究で構築したモデルを用いて、2007 年の改正建築基準 法施行以降に増加している構造スリットを有する集合住宅建物の解 析モデルを作成し、被害のクライテリアの設定には今後の課題を残 すものの、被害率の算定を行った。その結果、大阪ガス亘合波 $N 000 E$ $(120 \mathrm{~cm} / \mathrm{s})$ 入力で大破の場合スリットの有無により両者の被害率の 差は、約 1.5 倍あり、入力地震地震動の最大速度がより大きくなる と、両者の差は更に開くことを示した。これは、スリットを設ける ことで、建物の初期剛性および耐力が、より小さくなっているため と考えられ、スリットの有無が計算被害率に大きな影響を与えるこ とが分かった。

\section{謝辞}

本研究で用いた地震記録は、JR 鷹取駅は鉄道総合技術研究所が、 大阪ガス莫合供給所は大阪ガスが設置・収録したものである。また、 名古屋市営住宅の常時微動計測において伊藤誠氏、矢野斉氏をはじ めとする名古屋市住宅都市局職員の皆様のご協力を頂いた。名古屋 大学飛田潤准教授には、集合住宅の常時微動計測などでご協力を頂 いた。また、清水建設 (株) 技術研究所宮腰淳一博士には、兵庫県 南部地震での実被害などについて教示頂いた。ここに謝意を示す。

\section{参考文献}

1) 宮腰淳一, 林康裕, 渡辺宏一, 田村和夫 : 1995 年兵庫県南部地震の建物被 害に基づく建物の耐震性能評価, 構造工学論文集, Vol.43B, pp.269-276, 1997.3

2) 日本建築学会近畿支部鉄筋コンクリート部会 : 神戸市灘区および東灘区 $\mathrm{RC}$ 造建物全数調査, 1995 年兵庫県南部地震コンクリート系建物被害調査 報告書, pp.2-37, 1996.7

3) 中埜良昭, 岡田恒男: 信頼性理論による鉄筋コンクリート造建築物の耐震 安全性に関する研究, 日本建築学会構造系論文報告集, 第 406 号, pp.37-43, 1989.12

4) 白瀬陽一, 竹生修治, 平松悠, 福和伸夫, 宮腰淳一 : 耐震診断結果に基づ く低層鉄筋コンクリート造学校建物の地震被害率の予測に関する研究， 日本建築学会構造系論文集,第 No.607 号, pp.63-71, 2006.9

5) 小室達也, 北野靖彦, 広沢雅也 : 中低層鉄筋コンクリートラーメン構造 による共同住宅の耐震性能に関する研究, 構造工学論文 集,Vol.49B,pp.441-446,2003.3

6) 総務省消防庁ホームページ: http://www.fdma.go.jp/、2010.7.22 参照

7) 長戸健一郎, 川瀬博 : 建物被害データと再現強震動による RC 造建物群の 被害予測モデル, 日本建築学会構造系論文集, 第 544 号, pp.31-37, 2001.6

8) 保木和明,芳村学: 脆性的挙動を示寸既存中層鉄筋コンクリート造集合住 宅の耐震性評価,日本建築学会構造系論文集,第 619 号,pp.145-152,2006.12

9)（財）日本建築センター（監修：建設省住宅局建築指導課）：中高層壁式 ラーメン鉄筋コンクリート造設計施工指針・同解説, 1987.10

10) 下平祐司, 中村隆治, 益尾潔 : 既存建築物におけるコンクリート強度、中 性化深さならびに経年指標に関する統計資料, GBRC, 83, pp.3-10, 1996.7

11) (社) 日本建築学会 : 鉄筋コンクリート終局強度設計に関する資料, 1987.9

12) 中山治美, 大久保全陸 : 梁降状型 RC 造骨組に組み込まれた方立て壁型二 次壁の強度変形性状, コンクリート工学論文集, Vol.23No.2, pp.1111-1116, 2001

13) 飛田潤, 八木茂治, 福和伸夫, 西阪理永 : 常時微動計測による低層 R C 造 建物の振動性状と耐震指標に関する考察, 第 10 回日本地震工学シンポジ ウム論文集, pp.1671-1676, 1998.11

14) 松岡昌志, 翠川三郎: 国土数值情報を利用した地盤の平均 $\mathrm{S}$ 波速度の推 定, 日本建築学会構造系論文報告集, 第 443 号, pp.65-71, 1993.1

15)（社）日本建築学会 : 建築物の減衰, 2000.10

16) 芳村学, 上野裕美子, 中村孝也 : 既存低層鉄筋コンクリート建物の I s 值 と倒壊の関係, 日本建築学会構造系論文集, 第 587 号, pp.197-204, 2005.1

17) 兼近稔, 五十嵐克哉, 室井一夫, 秋野金次: スケルトンカープにひずみ速 度の影響を考慮した原子炉建屋耐震壁の弾塑性応答解析法, 日本建築学 会構造系論文集，第 495 号, pp.107-114, 1997.05

18) 藤井栄, 野村祥一, 大上実, 森田司郎 : 鉄筋コンクリート柱の挙動に及ぼ 寸載荷速度の影響（その 2 載荷速度の影響の検討）, 日本建築学会大会学 術講演梗概集, C, pp.413-414、1986.8

19) 芳村学, 中村孝也, 八木克己 : 既存低層鉄筋コンクリート造建物における 構造耐震指標（I s 値）と被災度の関係一地震応答解析による検討一, 日 本建築学会構造系論文集, 第 578 号, pp.107-114, 2004.4

20) 江戸川宏彰, 武田寿一：鉄筋コンクリート構造物の弾塑性地震応答フレ 一公解析, 日本建築学会大会学術講演梗概集, 構造系, pp.1877-1878, 1977.10

21）山原浩：動的解析における地盤の考え方, 土と基礎, Vol.19,No.8, pp. $7-15,1971.8$

22) N.Fukuwa and S.Nakai : A Study on Lateral Dashpots for Soil-Structure Interaction and its Application to a Simplified Technique, Soils and Foundations, Vol.29, No.3, pp.25-40, 1989.9

23) 杉本浩一, 護雅史, 福和伸夫 : 基礎の浮上りに伴う振動方向間の応答連成 効果を評価可能な地震応答解析モデルの構築, 日本建築学会大会学術講 演梗概集， B2， pp.683-684,2010.8

24) 神田順 : 損失費用モデルを用いた最適信頼性に基づく設計用地震荷重, 東 京大学大学院工学系研究科, p. 17, 1998.6

25) 林康裕, 宮腰淳一, 田才晃, 大野義照: 1995 年兵庫県南部地震における RC 造建物群の耐震性能, 日本建築学会構造系論文集, No.528, pp.135-142, 2000.2

26) 安井譲, 井口道雄, 赤木久真, 林康裕, 中村充 : 1995 年兵庫県南部地震に おける基礎有効入力動に関する考察, 日本建築学会構造系論文集, 第 512 号, pp.111-118, 1998.10

27) 中村豊, 上半文昭, 井上英司 : 1995 年兵庫県南部地震の地震動記録波形 と分析（II），JR 地震情報 No.23d，1996.3

28) 藤堂正喜, 西川孝夫: 兵庫県南部地震強震記録の建物応答への影響につい て, 日本建築学会大会学術講演梗概集, B2, pp.203-204, 1996. 